\title{
Społeczna percepcja szans i zagrożeń korzystania z nowych technologii komunikacyjnych
}

\begin{abstract}
Development and popularization of new communication technologies generate new dimensions of opportunities and threats associated with learning and using technologies as well as with their socio-cultural consequences. The article presents four dimensions of social perception of these threats and opportunities: creativity, representative potential, psychological attitude, privacy and control. They were distinguished on the basis of two research projects using qualitative research techniques. Particular attention was dedicated to generational usage of technology. In this way, the paper may be the basis for distinguishing the dimensions of technological competencies.
\end{abstract}

\section{Keywords:}

new media, new technologies, mobile technologies, qualitative research, technological competencies, technological generations

Nowe media i technologie komunikacyjne stały się naturalnym i oczywistym elementem życia społecznego. Według danych z „Diagnozy Społecznej” (Batorski,

1 Łukasz Rogowski, Zakład Badań Kultury Wizualnej i Materialnej, Instytut Socjologii, Wydział Nauk Społecznych, Uniwersytet im. Adama Mickiewicza w Poznaniu, Polska, lukasz.rogowski@ amu.edu.pl. 
2015) ponad 70\% gospodarstw domowych w Polsce jest wyposażonych w komputer i posiada dostęp do internetu, a korzysta z nich 2/3 Polaków. Także technologie mobilne stają się w coraz większym stopniu częścią codzienności - korzystanie ze smartfona deklaruje niemal połowa Polaków, a 1/4 gospodarstw domowych jest wyposażona w tablet. 36\% Polaków korzysta z mediów społecznościowych, 26\% Polaków wykorzystuje do tego technologie mobilne². Użytkownicy internetu to dokładnie połowa całej populacji świata, a użytkowanie technologii mobilnych deklaruje 66\% mieszkańców naszego globu33.

W takiej perspektywie otwierają się nowe pytania dotyczące zasad „uczenia się” technologii. Nie chodzi tu jednak tylko o wykorzystania technologii w instytucjach edukacyjnych bądź o sposoby nauczania technicznych umiejętności dotyczących obsługi urządzeń. Istotne jest bardziej uniwersalne ujęcie zagadnienia i potraktowanie technologii jako elementu kompetencji społeczno-kulturowych. Istniejące propozycje wyróżniania i kształtowania kompetencji technologicznych - nawet, jeżeli mają kompleksowy i spójny charakter (Gruhn, Brzózka-Złotnicka, 2014) - często nie odnoszą się do badań empirycznych. Z kolei te, które nawiązują do badań empirycznych, opierają się w dużej mierze na metodach i analizach ilościowych (Siuda, Strunża, 2012), które nie dają możliwości pełnego badawczego eksplorowania tego obszaru.

Celem, jaki stawiam sobie w niniejszym tekście, jest jakościowa analiza społecznej percepcji szans i zagrożeń związanych z korzystaniem z nowych technologii komunikacyjnych. Szczególną uwagę poświęcę postrzeganiu tego tematu z pespektywy kategorii wiekowych. W rezultacie chciałbym wyróżnić obszary, które są traktowane jako problemowe w korzystaniu z nowych technologii. Może to stanowić punkt wyjścia dla innego sposobu wyróżniania kompetencji technologicznych i innego podejścia do roli technologii w socjalizacji i edukacji. Punktem odniesienia będą dla mnie opinie użytkowników technologii zebrane w ramach dwóch projektów badawczych.

Pierwszy projekt to „Lepiej Widzieć. Kompetencja wizualna jako element kompetencji codzienności. Zarządzanie kompetencjami oraz rola nowych mediów w ich kształtowaniu i realizacji”. Był on realizowany w latach 2013-2014 przez Fundację SPOT. i Instytut Socjologii Uniwersytetu im. Adama Mickiewicza w Poznaniu, a finansowany ze środków Ministerstwa Kultury i Dziedzictwa Na-

22016 Digital Yearbook. We Are Social's Compendium of Key Digital Statistics and Data Points for 232 Countries Around the World. http://www.slideshare.net/wearesocialsg/2016-digital-yearbook.

3 Digital in 2017. Global Overview. A Collection of Internet, Social Media and Mobile Data from Around the World. http://www.slideshare.net/wearesocialsg/digital-in-2017-global-overview. 
rodowego w ramach programu Obserwatorium Kultury. Głównym celem projektu była diagnoza kompetencji wizualnych Polaków, co zostało zrealizowane w ramach badań jakościowych (60 wywiadów fotograficznych) i ilościowych (ogólnopolskie, reprezentatywne badania na próbie 1000 dorosłych Polaków). Kompetencja wizualna była w projekcie rozumiana w szeroki sposób - nie tylko jako wiedza o obrazach, ale także jako sposób zarządzania, interpretowania, wytwarzania wizualności. Stąd nacisk położony w badaniach na obszar nowych technologii.

Drugi projekt to „Możliwości i ograniczenia w korzystaniu z bankowości mobilnej w Polsce”, realizowany w latach 2014-2015 przez zespół badaczy z Instytutu Socjologii UAM. Partnerem strategicznym projektu jest Santander Universidades. Badania miały w większości charakter etnograficzny i oparte były na bliskiej współpracy z 36 klientami banku. Podsumowaniem badań były wywiady pogłębione, dotyczące korzystania z usług bankowych i bankowości mobilnej, w tym odnoszące się do szerokiego postrzegania społecznych funkcji technologii.

\section{ANTYDETERMINIZM TECHNOLOGICZNY JAKO PERSPEKTYWY OPISU ROLI TECHNOLOGII W ŻYCIU SPOŁECZNYM}

Wyróżnianie szans i zagrożeń związanych z korzystaniem z nowych technologii wymaga określenia zakresu i rodzaju sprawstwa technologii w procesach zmiany społecznej. Innymi słowy, to dylemat determinizmu i antydeterminizmu technologicznego. Determinizm technologiczny zakłada, że nowe rozwiązania technologiczne są elementem wpływającym na ludzkie sposoby myślenia, odczuwania i zachowania. Technologia staje się w tym ujęciu elementem sprawczym i punktem odniesienia dla podejmowanych działań. Antydeterminizm to z kolei założenie, że technologia nie kształtuje ludzkich potrzeb, lecz jest raczej odpowiedzią na ich przemiany i czynnikiem ułatwiającym dostosowanie się i popularyzację ich nowych form.

Determinizm i antydeterminizm technologiczny są często postrzegane jako skrajne punkty kontinuum, związane z budowaniem w świadomości dualistycznych, a tym samym nieco upraszczających podziałów. Dotyczą one przeciwstawiania sobie tego, co technologiczne i tego, co pozatechnologiczne; zapośredniczenia i bezpośredniości. Łączy się to często w wypowiedziach z innymi dualistycznymi podziałami: nowe/stare, teraz/dawniej, sztuczne/prawdziwe. Dość powszechnym przekonaniem jest to, że korzystanie z technologii może wprawdzie generować szereg nowych możliwości i otwierać nowe pola działania, ale w jakimś sensie odziera podejmowane aktywności z „aury”: 
No jak rozmowa bezpośrednia to jednak, tak jak teraz, to jednak się widzi kogoś, a przez telefon, no nie wiem, ileś kilometrów, ileś set, tysiące nawet, to jednak trochę oddala. [zastanawia się] No i pisanie listów było bardziej romantyczne niż sms-y [śmiech] [BM.36] $]^{4}$.

Nawet więc, jeżeli takie opinie nie pojawiają się wprost, to można odnieść wrażenie, że życie społeczne zaczyna być z powodu technologii postrzegane jako „mniej szczere”. Dotyczy to w szczególności wpływu technologii na relacje interpersonalne. Jednocześnie warto pamiętać o tym, że takie budowanie swoistego konfliktu niekoniecznie musi być związane z samą tylko technologią. Może tu się pojawiać szerzej rozumiana nostalgia za minionymi - choć niekoniecznie tak odległymi - czasami i doświadczeniami. Technologia staje się tu jedynie pretekstem do tęsknoty za młodością i punktem odniesienia dla tego, co już minęło.

Pytanie o relacje człowiek-technologia i o podmiotowość aktorów w tej relacji jest więc szczególnie ważne wtedy, gdy odniesiemy się nie tylko do podejmowanych działań, lecz również sposobów postrzegania, wartościowania i nazywania rzeczywistości społecznej (Postman, 1995). Rozpowszechnienie internetu funkcjonującego według logiki Web 2.0 wpłynęło na zmiany sposobów definiowania takich pojęć, jak prawda czy własność (Keen, 2007). Prawda nabrała charakteru konstruowanego, opierając się o społeczny dowód słuszności wynikający m.in. z reguł funkcjonowania mediów społecznościowych. Z kolei własność, wraz ze swobodą przepływu informacji i wymiany danych, stała się pojęciem płynnym, prowadząc do rozpowszechniania „intelektualnej kleptomanii”. W nieco innym kontekście, technologie mobilne zmieniły sposób postrzegania przestrzeni i czasu (Dholakiaa, Reyesb, Bonoffa, 2015), gdyż oferowana przez technologie możliwość ciągłego kontaktu daje również możliwość renegocjowania czasu i miejsca wydarzeń.

W niniejszym artykule przyjmuję natomiast dwa założenia dotyczące opisu społecznego funkcjonowania technologii. Pierwsze z nich definiuje społeczną rolę technologii nie jako bezpośredni wpływ na przebieg zachowań, lecz jako wyznaczaniu obszarów i granic ludzkich aktywności. W wymiarze interakcyjnym przebieg rozmowy, zakres czynności i zobowiązań może być zależny od formy technologii komunikacyjnej i wyznaczonej przez technologię roli społecznej

4 Fragmenty wywiadów są oznaczane skrótami, odpowiednio: LW (gdy pochodzą z projektu „Lepiej Widzieć”) lub BM (gdy pochodzą z projektu „Możliwości i ograniczenia w korzystaniu z bankowości mobilnej w Polsce”), a także numerem wywiadu. Transkrypcje wszystkich wywiadów znajdują się w formie cyfrowej w kolekcji autora. 
(Humphreys, 2005). Technologia może kształtować i reprodukować społeczne sposoby funkcjonowania stereotypów, szczególnie w kontekście autoprezentacji w internecie, a tym samym wpływać na genderowe relacje dominacji i podporządkowania (Bosch, 2011). W podobny sposób, uwarunkowania korzystania ze sprzętów i usług technologicznych, stworzone przez ich dostawców, wyznaczają bariery ludzkiej aktywności w różnych jej wymiarach: prawnym, społecznym, etycznym etc. (Couldry, van Dijck, 2015). Na poziomie makrospołecznym, zakres i możliwości korzystania z technologii mogą być z kolei wskaźnikiem globalnych nierówności społecznych, a tym samym kryterium podziału na kraje rozwinięte i rozwijające się (Rainie, Wellman, 2012). Oznacza to więc, że relacje pomiędzy człowiekiem a technologią mogą zostać potraktowane w niektórych wymiarach życia społecznego jako forma władzy.

Drugie założenie dotyczy tego, że technologia sama w sobie nie posiada esencjalistycznego statusu wyznaczającego jej cechy, wady i zalety. Powstają one dopiero w ramach relacji człowieka z urządzeniem. Jako że wartościowanie technologii jest zależne od sposobów i kontekstu użycia, sama w sobie nie może być ona również postrzegana w perspektywie moralnej. W takim ujęciu wpływ technologii na ludzkie zachowania ma charakter pośredni, nie jest przymuszaniem lub dosłownym sugerowaniem zachowaniem, lecz raczej otwieraniem nowych sposobów myślenia i bycia w świecie.

\section{GENERACYJNE KORZYSTANIE Z TECHNOLOGII}

Tematyka szans i zagrożeń technologicznych w szczególny sposób jest powiązana z wiekiem użytkowników. To właśnie wiek jest traktowany jako jeden z głównych czynników cyfrowego wykluczenia (van Dijk, 2010, s. 248-259), co także zauważają w swoich wypowiedziach badani:

Z wiekiem maleje jakaś gotowość do poznawania, młodzi są za pan brat z technologią, jakby moim zdaniem tych 20-40-latków daje radę, ale to powyżej 50-u lat to słabo. Jak dla mnie to głównie wiek powoduje te trudności, to nie kwestia wykształcenia, bo nawet jak ktoś jest magistrem prawa czy mechanikiem samochodowym to tę technologię na równi musi znać [BM.23].

Wskazywane są również pewne charakterystyczne dla seniorów i łatwo dostrzegalne cechy specyficzne korzystania przez nich z technologii, na bazie których można zdefiniować kategorię użytkownika i ich potrzeby: 
Jeżeli ktoś pyta o taki telefon, przykładowo, no część starszych osób no to jak widzę, że ktoś ma, ma... przychodzi z telefonem i chce go zmienić, widzę, że ma swój numer telefonu zapisany na tylniej klapce, no to już wiem, ze nie potrafi go sobie zapisać w pamięci telefonu. Więc od razu proponuję no taki najprostszy model [LW.45].

Ważniejsze są jednak dla mnie jakościowe różnice w postawach wobec technologii w różnych kategoriach wiekowych. Powstawanie „pokoleń technologicznych” (technological generation; Gardner, Davis, 2013, s. 52) to rezultat generacyjnych różnic w sposobach postrzegania świata i życia społecznego - ich możliwości i ograniczeń - wynikających z innych doświadczeń z technologią. Każde pokolenie dorasta wraz z innymi technologiami i innymi mediami. Co za tym idzie, inaczej postrzega też oferowane przez nie możliwości, szanse i zagrożenia.

Postawy dorosłych wobec korzystania przez młodych z technologii oscylują pomiędzy troskliwą wyrozumiałością (,mnie to niektóre rzeczy bawią, a to są ich problemy, z których się nie wolno absolutnie śmiać, trzeba z nimi rozmawiać"; LW.28) a opiekuńczą kontrolą („kocham ją i sprawdzam, podpatruję, co tam lajkuje, w jakie strony wchodzi, jakie zdjęcia umieszcza”; LW.35). Młodzi są często przez dorosłych postrzegani jako najbardziej podlegli manipulacjom opartym na technologii. Wskazywane są również inne szczegółowe zagrożenia wynikające z korzystania przez młodych z technologii, np. brak ruchu i otyłość. Intensywne korzystanie z technologii jest postrzegane często jako forma niedojrzałości i nieprzygotowania do przyszłego, dorosłego życia.

Przyjęcie założenia o istnieniu pokoleń technologicznych pociąga za sobą istotne konsekwencje dla opisywania szans i zagrożeń dotyczących korzystania z technologii, a także ich potencjału edukacyjnego. Często pojawia się bowiem pokusa, by własne doświadczenia z technologią traktować jako uniwersalny punkt odniesienia. Sensowna refleksja nad funkcjonowaniem technologii musi natomiast uwzględniać odmienne perspektywy jej wartościowania, uzależnione od innych przyzwyczajeń generacyjnych. W trakcie opisywania sposobów korzystania z technologii należy więc wyzbyć się chęci narzucania własnych doświadczeń pokoleniowych i przyjmowania ich jako jedynie słuszne. Stąd też wskazuję poniżej na wyróżniane często w literaturze cztery wymiary dotyczące generacyjnego postrzegania i korzystania z technologii, które mają duże znaczenia dla wskazywania szans i zagrożeń, jak również formułowania sugestii dotyczących działalności edukacyjnej.

Wymiar pierwszy to zapośredniczenie. Wśród wielu dorosłych istnieje przekonanie, że jednym z najważniejszych aspektów świadczących o prawdziwości 
i autentyczności relacji jest jej bezpośredniość. Technologia może otwierać i podtrzymywać relacje, są one wtedy jednak postrzegane, jako mniej wartościowe. Tymczasem dla młodych technologia także może być przestrzenią intymności (Khunou, 2012). Co więcej, technologie mobilne i media społecznościowe, oferujące nowe możliwości prezentowania siebie, odpowiadają oczekiwaniom młodych na temat autoprezentacji i zmniejszają lęk przed odrzuceniem.

Wymiar drugi to twórczość. Dla młodych podstawowym wyznacznikiem własnej tożsamości są na bieżąco wytwarzane technologicznie treści (Gardner, Davis, 2013, s. 60-91). „Co wytwarzam?” staje się ważniejszym pytaniem niż „kim jestem?”; to drugie jest warunkowane przez pierwsze. Co za tym idzie, tożsamość nabiera charakteru zdecydowanie procesualnego, a jej częsta zmiana nie jest przez młodych postrzegana jako coś nagannego. Takie doświadczenia łączą się z możliwościami oferowanymi przez technologie. Urządzenia i usługi technologiczne oferują coraz nowsze możliwości szybkiego tworzenia i przede wszystkim dzielenia się własnymi wytworami (wpisami, zdjęciami, filmami, nagraniami audio, linkami, komentarzami etc.).

Trzeci wymiar to wiarygodność. Skoncentrowanie młodych na wytwarzaniu skutkuje nowymi pytaniami dotyczącymi wartościowania powstających treści. W klasycznym podejściu dorosłych prawdziwość jest oceniana ze względu na zgodność treści pomiędzy sferami online i offline. Dla młodych sam ten podział ma charakter sztuczny, stąd wytwarzane są nowe kryteria oceniania i weryfikowania wiarygodności i prawdziwości treści zapośredniczonych technologicznie. Wielość tożsamości lub podawanie nieprawdziwych informacji w mediach społecznościowych nie jest przez młodych postrzegana jako kłamstwo lub problem psychologiczny, a raczej jako forma gry z konwencją oferowaną przez technologię (Boyd, 2014, s. 29-53). Posługiwanie się fikcyjnymi pseudonimami zamiast własnego imienia i nazwiska lub wykorzystywanie jako własnych zdjęć swoich idoli popkulturowych jest wśród młodych czymś naturalnym i powszechnym. Wiarygodność dotyczy także wykorzystywanych form komunikacji. Komunikacja zapośredniczona technologicznie (smsy, komunikatory, Snapchat) jest przez młodych postrzegana jako tak samo wiarygodna, a niekiedy wręcz wiarygodniejsza, niż kontakt bezpośredni lub rozmowa telefoniczna. Pokrywa się to z wcześniej omawianym wymiarem zapośredniczenia.

Czwartym wymiarem jest rywalizacja. Młodzi odchodzą od klasycznych, utopijnych sposobów postrzegania technologii jako współczesnej agory. Głównym zakładanym celem nie jest wyłącznie dążenie do porozumienia i swobodna wymiana informacji i poglądów - a przynajmniej nie ze wszystkimi. W tym wymiarze jeszcze bardziej uwydatnione zostaje istnienie pokoleń technologicznych - wy- 
różnianych nie tylko ze względu na inne poglądy/postawy wobec technologii, lecz również ze względu na definiowanie pokoleń jako „plemion” odnoszących się do siebie z nieufnością. Młodzi zdają sobie sprawę z tego, że ich aktywność technologiczna jest często monitorowana przez starszych. Stąd też wykorzystują swoje kompetencje technologiczne, aby przechytrzyć dorosłych (Chambers, 2006, s. 113-153). Kształtowanie własnych, pokoleniowych kodów komunikacyjnych czy też migrowanie do innych usług technologicznych są przykładami takiej nieformalnej rywalizacji i gry w „technologicznego chowanego”. Taka forma negocjowania własnej widzialności technologicznej w skrajnym przypadku może skutkować tymczasową rezygnacją z korzystania z technologii (Boyd, 2014, s. 199-213). Sfera pozatechnologiczna zaczyna być bowiem postrzegana jako bezpieczniejsza, gdyż znajdująca się poza kontrolą dorosłych (rodziców, nauczycieli).

Wymiary te, wyróżnione na podstawie literatury, warto rozwinąć o dwie kolejne cechy określające generacyjne korzystanie z nowych technologii, a dostrzegane przez uczestników opisywanych projektów badawczych. Pierwsza z nich związana jest z faktem, że swoisty dystans starszych wobec technologii nie jest postrzegany jako cecha nowa i specyficzna dla współczesności:

Jak tam 50 lat temu czy nie wiem jak babcia była młoda tak to oni też mieli takie współczesne jakby wynalazki na których tam praprababcia nie miała zielonego pojęcia i to wszystko idzie tak jak cywilizacja podąża z postępem technicznym [LW.44].

Jest to więc raczej uniwersalne zjawisko charakterystyczne także dla przeszłości. Seniorzy i osoby starsze są postrzegani jako ci, którzy w większości stają się kategorią częściowo wyobcowaną. Przyczyny tego faktu są przez badanych lokowane w postawach i potrzebach charakterystycznych dla kategorii wiekowych. Może to być dla przykładu lęk („osoba starsza, często też, niestety, zamknięta w sobie, samotna, która nawet nie tyle, co nie chce skorzystać technologii, ale boi się korzystania z tych nowych technologii”; BM.10) lub specyficzne emocje (,z wiekiem człowiek robi się coraz bardziej nerwowy, z wiekiem maleje pociąg do nowych rzeczy, inne rzeczy zaprzątają głowę”; BM.23).

Druga cecha jest jeszcze istotniejsza, gdyż wskazuje na potencjał relacji międzygeneracyjnych w odniesieniu do technologii - i szerzej, do funkcjonowania w świecie:

Ojejku oni to [uczyć innych o technologii - przyp. ŁR] uwielbiają. Pochwalili się wszystkim. Naprawdę ja podziwiam ich i ich rodziców, że oni jako 
takie małe ludki, gimnazjum to ile tam mają lat 12, 14 no to oni mają lepsze telefony niż my jako dorośli ludzie zarabiający, potrafią z tych telefonów wyciągać wszystko co tam mają i z filmami, i z jakimiś tam kombinacjami, i ze zdjęciami, tymi aparatami latają, biegają, tworzą, są w tym niesamowici. Oni jak wyczują, że człowiek potrzebuje pomocy czy coś chce od nich to oni czują się ważnie [BM.32].

Jak zostało wskazane wcześniej, w nawiązaniu do inspiracji literaturowych, zbyt często spotykamy się z sytuacją, w której korzystanie przez młodych z technologii jest deprecjonowane i krytykowane. $\mathrm{W}$ ten sposób dotychczasowe podziały międzygeneracyjne są dodatkowo intensyfikowane przez nowy wymiar. Jeżeli więc chcemy opisywać szanse i zagrożenia związane z korzystaniem z technologii, to należy przyjąć - na podstawie powyższych rozważań - dwa założenia. Po pierwsze, jeżeli mówimy o generacyjnym korzystaniu z technologii, to jest to oczywiście związane z bardziej szczegółowymi aspektami korzystania przez różne kategorie wiekowe, wynikającymi z ich różnych potrzeb i celów życiowych. Jednocześnie jednak można założyć, że istnieją pewne ogólne wymiary korzystania z technologii, które są wspólne dla wszystkich i na bazie których można wymienić wspólne wszystkim szanse i zagrożenia. Po drugie, konieczne jest wyzbycie się apodyktycznej postawy związanej z założeniem, że pewne kategorie potrafią lepiej, a inne gorzej rozpoznać szanse i zagrożenia technologiczne. O wiele lepszym rozwiązaniem jest, aby na podstawie wyróżnionych wcześniej ogólnych wymiarów szans i zagrożeń uszczegółowić je w kontakcie z przedstawicielami poszczególnych kategorii wiekowych - traktując ich jako swoistych „ekspertów” w swoim środowisku społecznym.

\section{SPOŁECZNA PERCEPCJA WSPÓŁCZESNYCH WYMIARÓW SZANS I ZAGROŻEŃ NOWYCH TECHNOLOGII}

Dotychczasowe rozważania chciałbym rozwinąć o wskazanie czterech, postrzeganych za szczególnie istotne, wymiarów korzystania z nowych technologii komunikacyjnych i powiązanych z nimi szans i zagrożeń. Trzeba jednak pamiętać, że uczestnikami obu projektów badawczych, do których nawiązuję, były wyłącznie osoby pełnoletnie, co wynikało zarówno z tematyki badań (szczególnie w przypadku projektu dotyczącego bankowości), jak i z uwarunkowań prawno-etycznych (zgoda rodziców lub opiekunów, która jest wymagana w przypadku badania osób niepełnoletnich). Mamy więc często do czynienia z sytuacjami, w których 
o zachowaniach technologicznych jakiejś kategorii wiekowej wypowiadają się członkowie innych kategorii. Interpretacja danych będzie uwzględniać ten fakt i zwracać uwagę na jego konsekwencje analityczne.

\subsection{KREACYJNOŚĆ}

Najważniejszym i najczęściej wskazywanym wymiarem szans i zagrożeń nowych technologii jest możliwość kształtowania sposobów postrzegania rzeczywistości, w tym także przekłamywania i manipulowania. Technologie są traktowane jako te, które nie tyle pokazują świat, ale wytwarzają jego wizerunek i poglądy na jego temat. Nie są więc lustrem rzeczywistości, ale raczej - w podobieństwie do tez Baudrillarda (2005) o precesji symulakrów - jej architektem:

Ostatnia manipulacja, nie wiadomo czy manipulacja, zdjęciami z ataku chemicznego w Syrii. Zdjęcia, które bez wątpienia robią wrażenie wstrząsające. Jest wątpliwość, uzasadniona, czy są to zdjęcia z jednego miejsca, czasu czy są to zmontowane jakieś materiały z różnych miejsc. Współcześnie nawet rządy posługują się tego typu manipulacjami w przekazach telewizyjnych, gazetowych, do osiągnięcia swoich celów [LW.11].

Dostrzeganie podobnych zagrożeń warunkuje powstawanie reakcji na nie, przejawiających się w specyficznych postawa i sposobach myślenia. Można je określić jako remedium na percypowane zagrożenia, a nawet jako szansę związaną z funkcjonowaniem technologii i będącą odpowiedzią na jej rozwój:

W związku z czym sama świadomość że takie coś ma miejsce i pewnego rodzaju dystans, czy wyrabiamy sobie własne zdanie na podstawie pojedynczej fotografii czy jakiejś sekwencji, to już ma znaczenie. Ale czy tak się dzieje, to wątpię. Większa część ludzi to na zasadzie: „przecież widziałaś w telewizji” albo „w gazecie pisali”. Czyli ten przekaz środków masowego przekazu ma wpływ na ludzi i wszyscy powinniśmy zdawać sobie z tego sprawę, a ci, którzy wykorzystują ten przekaz, na pewno sobie z tego zdają sprawę. A my jako odbiorcy powinniśmy o tym widzieć, żeby nie dać się ogłupić [LW.11].

Innymi słowy, remedium na zagrożenie związane z technologicznym kształtowaniem (a niekiedy manipulowaniem) rzeczywistości jest szansa oparta na rozwoju krytycznego myślenia. Dystans wobec technologii powinien być ukształtowany w taki sposób, aby obejmował możliwie wiele obszarów życia, w których 
technologia jest obecna: reklamę, media masowe, portale społecznościowe itd. Postawa dystansu i krytycznego myślenia umożliwia postrzeganie technologii nie jako głównego medium kształtowania życia i poglądów, ale raczej jako punkt odniesienia dla poglądów ukształtowanych uprzednio.

Warto jednak podkreślić, że takie technologiczne kształtowanie rzeczywistości może mieć dwie przyczyny, a tym samym dwojaki przebieg. Z jednej strony to, jak już zostało wspomniane w cytacie powyżej, celowe manipulacje, ukierunkowane na fałszowanie informacji i obrazu świata. Niektórzy z uczestników badań takie działania postrzegają jako element współczesnych kompetencji:

Mówię niestety bo jednak jest to oszustwo bo dobrze świadczy o człowieku który zna tę technikę, to jest po prostu umiejętność to jest technika którą się nabywa. Natomiast nie wiem czy to dobrze [LW.57].

Z drugiej strony technologiczne kształtowanie rzeczywistości nie musi wcale opierać się na chęci oszustwa, lecz wynika z cech stosowanego medium, co można potraktować jako kolejny wymiar szans i zagrożeń związanych z technologią.

\subsection{POTENCJAL REPREZENTACYJNY}

W tym przypadku chodzi bardziej o charakterystykę danej technologii, z której wynikają niedoskonałości w sposobie przekazywania informacji. Istotny jest więc także kontekst korzystania z technologii, rozszerzający zakres swoistej „odpowiedzialności” nadawcy/użytkownika za podejmowane działania.

To znaczy, że zawsze i wszędzie pokazują tylko wybrany przez osobę robiącą zdjęcie wycinek rzeczywistości. Wycinek nigdy nie reprezentuje całości tak. Aby poznać całość trzeba mieć cały zbiór tych wycinków, które ją tworzą, więc tak jak możemy obracać kawałkiem układanki i patrzeć na niego z różnych stron tak samo tym zdjęciem możemy operować w dowolny sposób, tak. Jeśli ktoś nie zna jego kontekstu, jego pochodzenia może zostać wprowadzony w błąd, bo właśnie tutaj jest ta gra subtelnych skojarzeń [LW.22].

Dla przykładu, uczestnicy badań mówią o tym, że zdjęcia „spłaszczają rzeczywistość” [LW.09], czyli że możliwości technologiczne nie oferują w pełni możliwości zarejestrowania i przekazania całej złożoności świata. Wymiar ten dotyczy dostrzeganego przez uczestników badań redukowania przez technologie owej złożoności. Co istotne, taka sytuacja jest coraz częściej wynikiem współgrania 
ze sobą cech technologii oraz oczekiwań jej użytkowników. Ograniczona długość przekazywanych technologicznie informacji (np. 140 znaków w wiadomości na Twitterze); większa popularność („,klikalność”) tych postów w mediach społecznościowych, które zawierają zdjęcia; powstawanie mediów społecznościowych skoncentrowanych wyłącznie na komunikatach wizualnych (Snapchat, Instagram); oparte na logice Web 2.0 technologiczne selekcjonowanie informacji dochodzących do użytkownika - to trendy, które wskazują na dążenie do technologicznej redukcji rzeczywistości.

Tego typu działania mogą być również postrzegane jako zaleta - redukowanie jest koniecznym zjawiskiem w sytuacji nadmiaru informacji w społeczeństwie informacyjnym. Stąd też konieczne jest samodzielne odnalezienie odpowiednich relacji pomiędzy zaangażowaniem w technologię a dystansem wobec niej:

\begin{abstract}
W moim dzieciństwie nie było sklepów z super zabawkami, natomiast miałam skądś katalogi zabawek i to było straszne, chciało się to wszystko mieć, a nie można było. Gdzieś tam tata pojechał do Niemiec i przywiózł mi zabawek, to okazywało się ze ta piękna lalka, która miała śpiewać i tańczyć to się rusza koślawo i wcale tak nie jest wspaniale. To były te momenty totalnego rozczarowania jeszcze większe, bo nie można było iść do sklepu i przekonać się, że ta zabawka wcale nie jest taka fajna i wtedy się już tego nie chciało, tylko to rozczarowanie było takie namacalne - w końcu miałam te wymarzona zabawkę, ale okazywało się, że ona wcale taka wymarzona nie była. Na przykładzie tych kilku rozczarowań nauczyłam się, że tak to nie tak wcale jest w rzeczywistości [LW.08].
\end{abstract}

Odpowiedzią na zagrożenie technologicznego kontekstualizowania i redukowania rzeczywistości jest nastawienie na bezpośredni kontakt z nią. Taka nauka - trochę na zasadzie prób i błędów - może oczywiście, jak wspomina uczestniczka badań, prowadzić do rozczarowań. W rezultacie jednak będzie mogła uczestniczyć w kształtowaniu dwóch cech. Po pierwsze, ukierunkuje myślenie na potencjał reprezentacyjny technologii, mocne i słabe strony wykorzystywania różnych mediów, określi relacje pomiędzy doświadczaną bezpośrednio rzeczywistością a jej technologiczną reprezentacją. Po drugie, co za tym idzie, podtrzyma i zintensyfikuje wspomniane wcześniej krytyczne myślenie, przede wszystkim w obszarze namysłu nad cechami technologii i motywacjami osób zaangażowanych w jej wykorzystywanie. 


\subsection{NASTAWIENIE PSYCHOLOGICZNE}

Można zauważyć, że dla uczestników badań mówienie o własnych doświadczeniach z technologią sprawiało pewne kłopoty:

Nie wiem, zabijacz czasu, na przykład. Jak gdzieś jestem to sobie mogę zabić czas, łączę się z Internetem, coś tam mogę sobie posprawdzać, coś, gdzieś tam w kolejce u lekarza jestem, czy coś, nie wiem [myśli]. Sprawdzić to konto, czy już tam wypłynął przelew, czy nie wpłynął, czy wyszedł, czy nie wyszedł. Takie rzeczy. No nie wiem, jak to ubrać w słowa, że tak powiem [BM.5].

Coraz trudniejsze udyskursowienie własnych relacji z technologią może wynikać z dwóch powodów. Po pierwsze, technologia w coraz większym stopniu nabiera charakteru ucieleśnionego - zarówno ze względu na charakter interfejsów (obsługa poprzez dotyk) jak i poprzez swoistą cyborgizację, bezpośrednie łączenie technologii z ciałem (np. urządzenia wearables). Po drugie, korzystanie z technologii staje się w coraz większym stopniu nawykowe, często nawet na zasadzie pewnych odruchów (np. sprawdzanie godziny na smartfonie), z których nie do końca zdajemy sobie sprawy. Zjawiska te mogą zostać potraktowane jako wyzwania metodologiczne badań nad technologią - co jednak wykracza poza ramy niniejszego tekstu. W tym miejscu istotne jest to, że korzystanie z technologii jest „działaniem w międzyczasie”. Doświadczanym i dostrzeganym skutkiem takiego funkcjonowania technologii jest poczucie rozproszenia:

W momencie kiedy na przykład czytam książkę w międzyczasie przynajmniej kilka razy odrywam się, żeby spojrzeć na maile, ewentualnie zobaczyć co się dzieje na Facebooku, odczytać sms, kiedyś tego nie było. Mam wrażenie, że tak bardziej żyjemy przez to w pośpiechu [BM.04].

Przede wszystkim technologia przestaje być wyłącznie elementem pracy lub innych działań ukierunkowanych zadaniowo. Staje się natomiast towarzyszem innych czynności. To często ukierunkowanie na zabicie nudy, wypełnienie chwili wolnego czasu, jak również chęć utrzymania poczucia kontroli nad otoczeniem. Sama technologia zachęca do takich postaw, choćby poprzez powiadomienia push z aplikacjach mobilnych.

Dlatego też ważnym i pożądanym elementem korzystania z technologii jest wykształcenie w sobie możliwości rozdzielenia sfer i czynności warunkowanych 
i niewarunkowanych technologicznie - co może zostać potraktowane jako remedium i szansa odpowiadająca opisywanemu zagrożeniu:

Kiedy mam czas wolny to mam czas wolny, potrafię wyłączyć telefon i jak Pan tu też sam zauważył, też potrafię nie odebrać telefonu. No jak mam czas wolny to mam czas wolny, o tak. A kiedy pracuję to pracuję [LW.14].

\subsection{PRYWATNOŚĆ I KONTROLA}

Ostatni wymiar technologicznych szans i zagrożeń, o którym warto wspomnieć na podstawie zrealizowanych badań, to kwestia technologicznego nadzoru i świadomości jego funkcjonowania. Oczywiście szeroko rozumiany nadzór - choćby w formie monitoringu i kamer przemysłowych - jest oczywistym i powszechnie znanym elementem współczesnego życia społecznego, nie bez powodu zwanego „społeczeństwem nadzoru” (Lyon, 2001). W tym miejscu bardziej interesujące są nowe formy nadzoru, choćby te skoncentrowane wokół mediów społecznościowych:

Jestem przyzwyczajona, że wszędzie jest monitoring. Ale na przykład ostatnio pojawił się taki program w Internecie „Spotify” to jest do słuchania muzyki. Ja się na niego zalogowałam przy pomocy Facebooka i pierwszy raz w życiu poczułam, że to, że portal społecznościowy Facebook na moim profilu przy użyciu Spotify wrzuca wszystkie utwory jakie ja odtwarzam w ciągu dnia. Poczułam się źle z tym, znaczy że każdy mój ruch jest publikowany [...]. A tutaj nagle cały mój dzień jest publikowany na Facebook-u. Wtedy poczułam się bardzo źle z tym, że nagle wszyscy wiedzą o której godzinie jakiej muzyki słucham [LW.05].

Nowe technologie w coraz większym stopniu są oparte o logikę społecznościową, która jednocześnie zachęca do dzielenia się swoimi doświadczeniami z innymi i do przekazywania danych o swojej aktywności administratorom i właścicielom mediów/ portali. Standardem jest współcześnie konieczność samodzielnego regulowania i kontrolowania ustawień prywatności i tego, jaki zakres informacji o naszej aktywności będzie dostępny innym. Ma to znaczenie szczególnie wtedy, gdy zaczynamy dopiero używać mediów/technologii/aplikacji i gdy nie jesteśmy jeszcze w pełni zaznajomieni z zasadami ich funkcjonowania. To właśnie wtedy mogą się pojawić sytuacje, o których wspomina uczestniczka badań - gdy dopiero z czasem orientujemy się, że nasza aktywność jest rejestrowana i udostępniana innym. 
Odpowiedzią na nowe formy nadzoru technologicznego może być rozbudowywanie i poszerzanie zakresu kontaktów społecznych, także na aspekt społecznego wsparcia technologicznego:

Powiem tak, kiedyś chciałam Facebooka zacząć używać, ale w rozmowie ze znajomymi odradzono mi, mimo, że mam jeszcze gdzieś tam jakieś... bo ciągle dostaję... informacje z Facebooka, ale nie odpowiadam, jeszcze się nie wycofałam zupełnie. Używam Google tylko, a do kontaktów ze znajomymi używam poczty [LW.18].

Wsparcie społeczne pochodzące od znajomych jest więc definiowane jako odmienne od tego, które formułowane jest przez oficjalne kanały mediów/technologii/portali. Wzrastająca świadomość tego, że te drugie nastawione są na zysk, w tym również ten związany z gromadzeniem informacji na temat nas i naszych aktywności, buduje nieufność wobec tych kanałów. W związku z tym rozbudowa sieci społecznych i wykorzystywanie ich do nieformalnego wspierania własnych aktywności technologicznych staje się swoistym „działaniem oddolnym” i formą społecznego oporu wobec nadzoru.

\section{PODSUMOWANIE}

Wymienione powyżej na podstawie badań wymiary szans i zagrożeń związanych z technologiami zostały ze sobą zestawione w poniższej tabeli:

Tabela 1.

\begin{tabular}{lll}
\hline Wymiar & Zagrożenie & Szansa/remedium \\
\hline Kreacyjność & Kształtowanie rzeczywistości & Dystans i krytyczne myślenie \\
\hline Potencjał reprezentacyjny & Redukcja rzeczywistości & $\begin{array}{l}\text { Bezpośredni kontakt z rzeczy- } \\
\text { wistością }\end{array}$ \\
\hline Nastawienie psychologiczne & Rozproszenie & Rozdzielanie sfer życia \\
\hline Prywatność i kontrola & Nie/świadomość nadzoru & $\begin{array}{l}\text { Rozbudowa i uwiarygodnie- } \\
\text { nie sieci społecznych }\end{array}$ \\
\hline
\end{tabular}

Źródło: Opracowanie własne.

Wymienione wymiary nie są listą wyczerpującą i skończoną, lecz raczej punktem wyjścia do dalszej dyskusji na omawiany temat. Jednocześnie warto na ich podstawie wyróżnić dwie wskazówki dotyczące badania szans i zagrożeń 
technologii i ich społeczno-edukacyjnego wykorzystywania przy opracowywaniu zagadnienia kompetencji technologicznych.

Po pierwsze, tak jak zagrożenia w tabeli są bezpośrednio związane z technologiami i ich wąsko rozumianym funkcjonowaniem, tak odpowiadające im szanse odnoszą się do innych, zazwyczaj pozatechnologicznych wymiarów. Takie rozwiązania, oparte na wypowiedziach uczestników badań, potwierdzają przyjęte wcześniej założenia dotyczące relacji pomiędzy determinizmem i antydeterminizmem technologicznym. Badani, dostrzegając zagrożenia technologiczne, remedium na nie lokują nie w urządzeniach, ale we własnych postawach i sposobach myślenia. Technologia raczej więc tu wyznacza granice działań, a nie bezpośrednio wpływa na ich przebieg.

PO drugie, co za tym idzie, wskazane w tabeli szanse mogą mieć charakter uniwersalny, gdyż dotyczą nie tylko nowych technologii komunikacyjnych, a raczej specyficznych postaw wobec rzeczywistości społecznej. Stanowią więc element kompetencji codzienności (Rogowski, 2014), rozumianej jako sposób mediowania kompetencji szczegółowych zapewniających korzystne i odpowiedzialne funkcjonowanie w rzeczywistości społecznej. Technologia i związane z nią praktyki są jednym z wielu możliwych kontekstów, w ramach których wymiary tak rozumianej kompetencji codzienności mogłyby być realizowane.

\section{Bibliografia}

2016 Digital Yearbook. We Are Social's Compendium of Key Digital Statistics and Data Points for 232 Countries Around the World. Pobrane z: http://www.slideshare.net/ wearesocialsg/2016-digital-yearbook

Batorski, D. (2015). Technologie i media w domach i w życiu Polaków. W: J. Czapiński, T. Panek (red.), Diagnoza Społeczna 2015 (s. 355-377). Warszawa: Rada Monitoringu Społecznego.

Baudrillard, J. (2005). Symulakry i symulacja. Warszawa: Sic!

Bosch, T. (2011). Young women and „technologies of the self”: Social networking and sexualities. Agenda: Empowering women for gender equity, 25:4, s. 75-86. DOI: http:// dx.doi.org/10.1080/10130950.2011.630579

Boyd, D. (2014). It's complicated. The Social Lives of Networked Teens. New Haven, London: Yale University Press.

Chabers, D. (2006). New Social Ties. Contemporary Connections in a Fragmented Society. Hampshire, New York: Palgrave Macmillan.

Couldry, N., van Dijck, J. (2015). Researching Social Media as if the Social Mattered. Social Media + Society, 1(2), s. 1-7. DOI: http://dx.doi.org/10.1177\%2F2056305115604174 Dholakiaa, N., Reyesb, I., Bonoffa, J. (2015). Mobile media: from legato to staccato, 
isochronal consumptionscapes. Consumption Markets \& Culture, 18(1), s. 10-24. DOI: http://dx.doi.org/10.1080/10253866.2014.899216

Digital in 2017. Global Overview. A Collection of Internet, Social Media and Mobile Data from Around the World. Pobrane z: http://www.slideshare.net/wearesocialsg/ digital-in-2017-global-overview

Gardner, H., Davis, K. (2013). The App Generation. How Today’s Youth Navigate Identity, Intimacy and Imagination in a Digital World. New Haven, London: Yale University Press.

Gruhn, A., Brzózka-Złotnicka, I. (2014). Katalog kompetencji medialnych, informacyjnych i cyfrowych. Warszawa: Fundacja Nowoczesna Polska. Pobrano z: http://edukacjamedialna.edu.pl/media/chunks/attachment/Katalog_kompetencji_medialnych_2014_EudBrrI.pdf

Humphreys, L. (2005). Cellphones in public: social interactions in a wireless era. New media \& society, 7(6), s. 810-833. DOI: http://dx.doi.org/10.1177\%2F1461444805058164

Keen, A. (2007). Kult amatora. Jak internet niszczy kulturę? Warszawa: Wydawnictwa Akademickie i Profesjonalne.

Khunou, G. (2012). Making love possible: cell phones and intimate relationships. African Identities, 10(2), s. 169-179. DOI: http://dx.doi.org/10.1080/14725843.2012.657860

Lyon, D. (2001). Surveillance Society. Monitoring Everyday Life. Buckinghman, Philadelphia: Oxford University Press.

Postman, N. (1995). Technopol. Triumf techniki nad kulturą. Warszawa: Warszawskie Wydawnictwo Literackie Muza SA.

Rainie, L., Wellman, B. (2012). Networked. The New Social Operating System. Cambridge, London: The MIT Press.

Rogowski, Ł. (2014). Kompetencja codzienności. Zarys problematyki i propozycja badań. Poznań. Pobrane z: http://lepiejwidziec.com/pub/uploaddocs/kompetencja_codziennosci_-_zarys_problematyki_i_propozycja_badan.pdf

Siuda, P, Strunża, G. (red.) (2012). Dzieci sieci 2.0. Kompetencje komunikacyjne młodych, Gdańsk: Instytut Kultury Miejskiej. Pobrano z: http://dziecisieci.ikm.gda.pl/images/ Dzieci_sieci_2.0.pdf

Van Dijk, J. (2010). Społeczne aspekty nowych mediów. Warszawa: Wydawnictwo Naukowe PWN. 